\title{
TWO NEW SPECIES OF LICUALA \\ (ARECACEAE; CORYPHOIDEAE) \\ FROM WESTERN NEW GUINEA
}

\author{
CHARLIE D. HEATUBUN ${ }^{1} \&$ ANDERS S. BARFOD ${ }^{2}$
}

\begin{abstract}
SUMMARY
Fieldwork in Western New Guinea has revealed a number of new palm species. Here we describe two small-sized species of Licuala with unbranched partial inflorescences.
\end{abstract}

Key words: Arecaceae, Coryphoideae, Licuala, palms, New Guinea.

\section{INTRODUCTION}

Recent field work, conducted under the auspices of the Palms of New Guinea Project, has led to the discovery of a number of new palm species in the Indonesian provinces of Papua and West Papua. With an estimated number of 32 species Licuala is the second largest genus in New Guinea only surpassed by the genus Calamus which comprises about 60 species (Barfod et al. 2001, Baker \& Dransfield 2006). Many of the New Guinean species of Licuala display character combinations that deviate markedly from species that are not present on the island. This applies particularly to the fruiting morphology. A number of species such as Licuala beccariana and the recently described L. crassiflora Barfod and L. longispadix Banka \& Barfod have large-sized fruits with grooved endocarps (Barfod 2000, Banka \& Barfod 2004).

Here two new species of Licuala are described. They are both small palms with unbranched partial inflorescences. One species has leaves that are divided into narrow segments reminiscent of grass leaves, whereas the other has entire, bifid leaves. The two species are known from relatively few and mostly recent collections.

\section{MATERIALS AND METHODS}

Herbarium specimens from the following herbaria were available to us: AAU, BM, BO, BRI, CAN, K, L, LAE, MAN, MO. All measurements were derived from dried voucher specimens. The flowers were boiled prior to longitudinal sectioning and measured in a stereoscope using a stage micrometer. Indication of colour is based on field observations and label information. The line drawings were rendered from voucher specimens

1) Departemen Biologi, Sekolah Pascasarjana Institut Pertanian Bogor, Darmaga, Bogor 16680, Jawa Barat, Indonesia. (Permanent address: Fakultas Kehutanan Universitas Papua, Amban, Manokwari 98314, Papua Barat, Indonesia); corresponding author: charlie_deheatboen@yahoo.com.

2) Department of Biological Sciences, University of Aarhus, Ny Munkegade, bygn. 1540, DK-8000 Aarhus C, Denmark. 


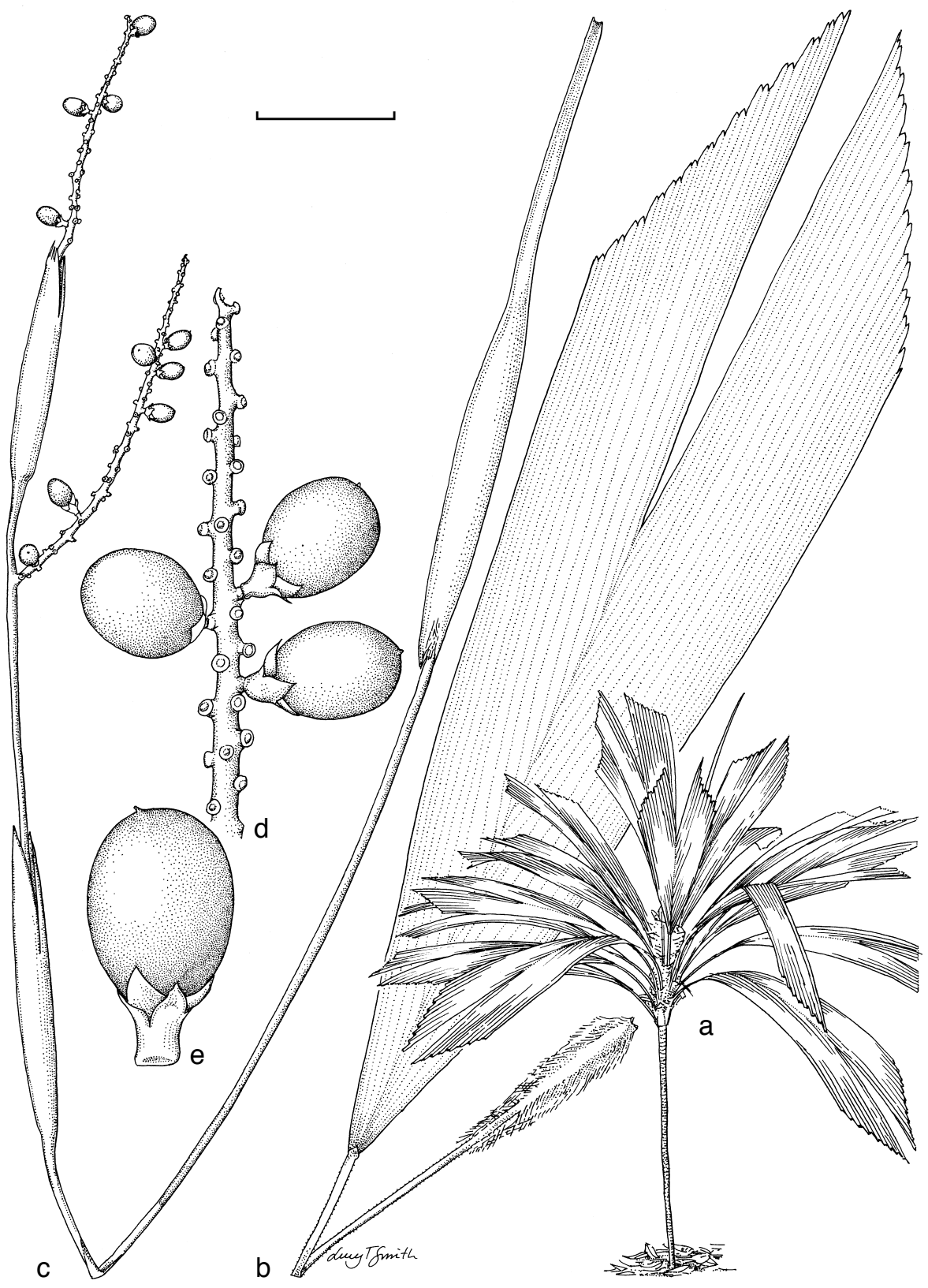

Fig. 1. Licuala bifida Heatubun \& Barfod. a. Habit; b. leaf; c. infructescence; d. detail of infructescence; e. fruit. - Scale bar: $\mathrm{a}=20 \mathrm{~cm}, \mathrm{~b}=8 \mathrm{~cm}, \mathrm{c}=4 \mathrm{~cm}, \mathrm{~d}=1 \mathrm{~mm}, \mathrm{e}=7 \mathrm{~mm}$ (a: from photograph taken by Charlie Heatubun; b-e: Wally $839, \mathrm{~K})$. 
except for the habit drawing on Fig. 1, which was based on a colour photograph from the type locality.

\title{
DESCRIPTION OF SPECIES
}

\section{Licuala bifida Heatubun \& Barfod, spec. nov. - Fig. 1}

\author{
Palma solitaria, foliis bifidis et inflorescentia partiali spicata. - Typus: Wally 839 (holo \\ MAN!; iso BO, K!), Indonesia, West Papua province, Teluk Bintuni regency (previously \\ Manokwari regency), Merdey.
}

Solitary, small to medium-sized palm. Stem to $2 \mathrm{~m}$ high, to $3 \mathrm{~cm}$ diam., internodes very short. Leaves c. 18 in crown; petiole $13-30 \mathrm{~cm}$ long, $3-6 \mathrm{~mm}$ wide at the base to $3-6$ $\mathrm{mm}$ across towards the apex, adaxial face flattened at the apex and shallowly channelled at the base, abaxial face rounded, greenish yellow in colour, armed; blade small, $17-20 \mathrm{~cm}$ wide, simple-bifid leaves, adaxial light green, abaxial whitish, c. $112 \mathrm{~cm}$ long, truncate at apex and $5-10 \mathrm{~mm}$ wide, lobe split $30-35 \mathrm{~cm}$ from apex to rachis, rachis c. $40 \mathrm{~cm}$ long. Inflorescences 1 or 2 in a single palm, shorter than leaves, $82-90 \mathrm{~cm}$ long, branched to only 2 first-order branches; peduncle $67-75 \mathrm{~cm}$ long; prophyll 21-25 by $1.5-2 \mathrm{~mm}$; peduncular bracts lacking; rachis elongate, c. $16 \mathrm{~cm}$ long; rachis bract tubular, flattened, 2-keeled, $40-50$ by $1 \mathrm{~mm}$, covered with brown and black indument, mouth loosely sheathing, splitting on one side, apex pointed; first-order branches close to or slightly away from mouth of rachis bract $(\mathrm{c} .12 \mathrm{~cm})$; rachillae $8-12 \mathrm{~cm}$ long, 2-3 $\mathrm{mm}$ wide. Flowers unknown. Fruits globose, 7-10 mm diam., orange when mature; seed globose 5-8 mm diam.; endocarp smooth; endosperm homogeneous.

Distribution - This has been reported from a restricted area in the Merdey valley (now Moskona Utara district of Teluk Bintuni regency), in South-Central Bird's Head Peninsula in Western New Guinea.

Habitat - This palm grows in lowland forest to $500 \mathrm{~m}$ asl.

Conservation status - Data deficient but probably under threat due to its restricted distribution.

Vernacular name and uses - Not recorded.

Note - The only New Guinea Licuala recorded so far with bifid leaves. The inflorescence structure is reminiscent of L. graminifolia from which it differs by normally having two partial inflorescences. Flowering material of this species has not yet been collected.

Etymology - The name refers to the entire, bifid leaves.

Additional specimen studied:

INDONESIA. West Papua: Heatubun s.n. (MAN!), Manokwari, Merdey district (now is Moskona Utara district of Teluk Bintuni regency), forest behind Merdey village.

2. Licuala graminifolia Heatubun \& Barfod, spec. nov. - Fig. 2

\footnotetext{
Palma parva solitaria, foliis subtiliter divisis et inflorescentia non ramosa. Ab L. bifida, et ceteris speciebus inflorescentiam spicam praebens, folia in segmentis augustis divisis statim diagnoscenda. - Typus: Van Royen \& Sleumer 7345 (holo L!; iso K!), Indonesia, West Papua province (Vogelkop Peninsula), Kebar Valley, opposite Andjai, path to Hatai, above Aremi village, 800 m, 20 November 1961.
} 


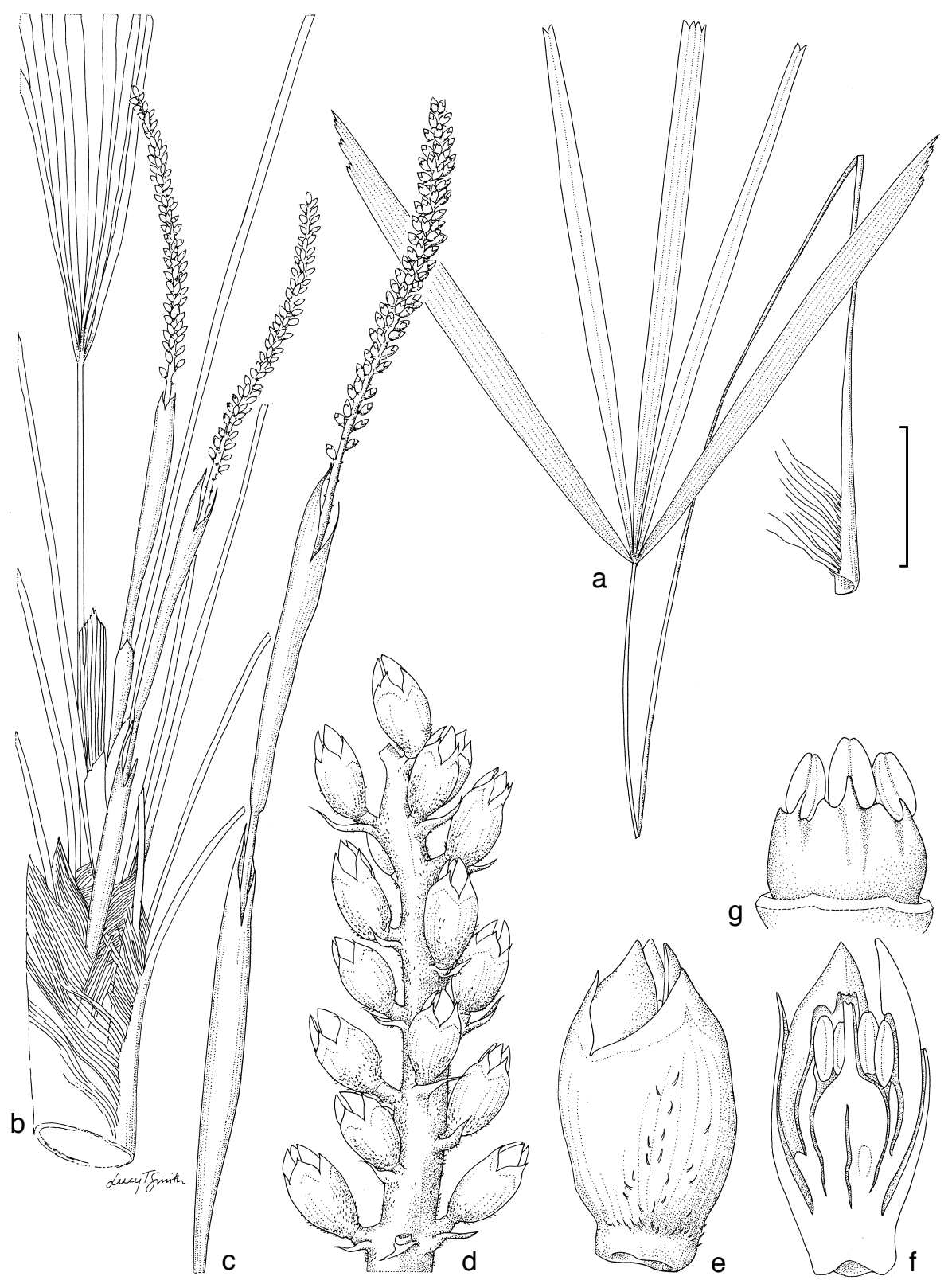

Fig. 2. Licuala graminifolia Heatubun \& Barfod. a. Leaf; b. stem apex with leaf sheaths and inflorescences; c. inflorescence; d. detail of the partial inflorescence; e. flower; f. longitudinal section of flower; g. staminal ring. - Scale bar: $\mathrm{a}=6 \mathrm{~cm}, \mathrm{~b}=2.5 \mathrm{~cm}, \mathrm{c}=2 \mathrm{~cm}, \mathrm{~d}=3 \mathrm{~mm}, \mathrm{e}, \mathrm{f}=1.2 \mathrm{~mm}, \mathrm{~g}=1$ mm (all: Van Royen \& Sleumer 7345, K). 
Solitary, small palm. Stem acaulescent to about $1 \mathrm{~m}$ high, $1.5 \mathrm{~cm}$ diam., internodes short. Leaves c. 9 in crown, sheath disintegrating into a loose mesh of fine fibres; petiole $40-65 \mathrm{~cm}$ long, 2-4 $\mathrm{mm}$ wide at the base to $2-2.5 \mathrm{~mm}$ across towards the apex, adaxially flattened to shallowly channelled towards the base, abaxially rounded, unarmed; lamina fan-shaped in outline, $30-50 \mathrm{~cm}$ wide, divided into 9-11 segments, narrowly wedge-shaped or with slightly curved lateral margins, all segments with 1-3 adaxial ribs, more or less equal in length $20-35 \mathrm{~cm}$, indentations leading to adaxial ribs $2-3$ mm long, those leading to abaxial splits considerably shorter, mid-segment truncate, 6-9 mm wide at apex, basal segment obliquely truncate at apex, usually wider than the mid-segment. Inflorescences 1 or 2 in one palm individual, shorter than leaves, 20-60 $\mathrm{cm}$ long, carrying one spicate, partial inflorescence; prophyll $10-12 \mathrm{~cm}$ long and up to $10 \mathrm{~mm}$ wide, loosely fitting, splitting on one side; peduncle as measured to insertion of rachis bract 8-20 cm long; peduncular bracts lacking; rachis bract tubular, $5-9 \mathrm{~cm}$ long and up to $7 \mathrm{~mm}$ wide, covered with scattered ferruginous ramenta basally, loosely fitting to weakly inflated towards the apex, with 2 or 3 splits, 5-12 mm long; peduncle of partial inflorescence equal to or slightly exceeding rachis in length; rachilla 6-8 cm long, 1-2 mm wide. Flowers solitary, hermaphroditic, bullet-shaped $2.5-3 \mathrm{~mm}$ long; flowers borne on elevated points, subtending bract c. $1 \mathrm{~mm}$ long, bracteole more or less conspicuous at a lateral position, pedicel very short, calyx $2.2-2.8 \mathrm{~mm}$ long, hyaline distally, with three $0.4-0.6 \mathrm{~mm}$ long pointed lobes; corolla $2-2.2 \mathrm{~mm}$ long, splitting deeply to c. $5 \mathrm{~mm}$ above the base; androecium fused to corolla for $0.5-0.6$ $\mathrm{mm}$, staminal ring c. $0.5 \mathrm{~mm}$ high; anthers inconspicuously inserted in 2 levels, $0.5-0.6$ $\mathrm{mm}$ long; ovary $0.7-0.8 \mathrm{~mm}$ long, attenuate apically; style $0.6-0.7 \mathrm{~mm}$ long; locules in lower half. Fruits globose, 8-10 mm diam., green; seed 6-8 mm diam.; endocarp smooth; endosperm homogeneous.

Distribution - Known from several collections in Western New Guinea.

Habitat - This palm is distributed in lowland rain forest ranging up to $800 \mathrm{~m}$ asl. It is often found in association with Vatica rassak Blume.

Conservation status - No immediate concern since it is quite common locally but further research is required.

Vernacular name and uses - Pupuru (Jamur dialect) is the collective term for species of Licuala in the Lake Jamur area. No specific use of this palm has been recorded.

Note - Licuala graminifolia is similar to L. bifida in the inflorescence structure; but in contrast to this, the inflorescence is unbranched with only one, spicate, partial inflorescence. The leaf is easily distinguished by the fine segmentation of the blade.

Etymology - The name refers to the grass-like leaf segments.

Additional specimens studied:

INDONESIA. West Papua: Heatubun 332 (K!, MAN!), Kaimana regency (previously Fakfak regency), Teluk Etna district, km 45 logging road to Lake Jamur; Heatubun 334 (MAN!), idem.

\section{ACKNOWLEDGEMENTS}

The authors are grateful to the keepers of the herbaria BM, BO, BRI, CAN, K, L, LAE, MAN and MO who sent material of Licuala on loan to AAU. The fieldwork to Lake Jamur and Sorong Selatan was funded by Royal Botanic Gardens, Kew through the Palms of New Guinea Project. The plates were skilfully rendered by Lucy T. Smith for the Palms of New Guinea Project. Dr. William Baker 
kindly granted us permission to use them in this paper. CDH would like to thank the staff of AAU, $\mathrm{K}$, and L for ground support and hospitality during his visits in June-July 2007.

\section{REFERENCES}

Baker, W. \& J. Dransfield. 2006. Field guide to palms of New Guinea. Royal Botanic Gardens, Kew. Banka, R. \& A.S. Barfod. 2004. A new spectacular species of Licuala (Arecaceae, Coryphoideae) from New Guinea. Kew Bulletin 59: 73-75.

Barfod, A.S. 2000. A new species of Licuala from New Guinea. Palms 44: 198-201.

Barfod, A.S., R. Banka \& J.L. Dowe. 2001. Field guide to palms in Papua New Guinea. AAU reports 40: $1-77$. 